\title{
DESCRIBING DIALOGIC TEACHING AND \\ LEARNING IN A MALAYSIAN HIGHER LEARNING \\ INSTITUTION SETTING: A DISCUSSION OF ITS OBSERVATIONAL FINDINGS
}

\author{
Anis Shaari*, Hairul Nizam Ismail and Aswati Hamzah \\ School of Educational Studies, Universiti Sains Malaysia, \\ 11800 USM Pulau Pinang, Malaysia \\ *Corresponding author: anisshaari@gmail.com
}

Published date: 10 August 2018

To cite this article: Anis Shaari, Hairul Nizam Ismail, \& Aswati Hamzah. (2017). Describing dialogic teaching and learning in a Malaysian higher learning institution setting: A discussion of its observational findings. Asia Pacific Journal of Educators and Education, 32, 1-19. https://doi.org/10.21315/apjee2017.32.1

To link to this article: https://doi.org/10.21315/apjee2017.32.1

\begin{abstract}
Education has always been fundamental in an individual's life and in a nation's survival, at large. Synonymous to the process of teaching and learning, it is always expected to meet the demands of many parties including the community, the educational institution itself and the country. As for a higher learning milieu, the teaching and learning process is enlightened with various methodologies in lesson delivery. Among all, dialogic teaching and learning is found to be an appropriate pedagogical method which offers a great deal of benefits. An educator was identified to practise such a method and it was the objective of the research to uncover the practice in a Malaysian tertiary education context. Employing a qualitative approach, the research implicated an educator and 41 learners who were directly involved in the dialogic teaching and learning. Through a classroom observation technique, significant episodes were recorded and narrated. This paper aims at presenting the observational findings, thus, suggesting a number of pedagogical implications.
\end{abstract}

Keywords: dialogue, teaching and learning, higher learning

\section{INTRODUCTION}

In embracing the 21 st century teaching and learning, the aspirations are to produce individuals with diverse attributes. This depicts the need of empowering learners with critical and creative thinking skills, communicative skills, collaborative skills 
as well as ethics and leadership skills (Rosnani Hashim, 2017). Nevertheless, in Malaysian education context, the pedagogical practices seem to less reflect such aspirations when they are often associated with lectures, tutorials, printed materials, notes and reference books (Abdul Shakour Preece \& Adila Juperi, 2014; Norizan Md. Nor, Noriah Mohamad, Hasuria Che Omar, \& Ruslan Rainis, 2010). This phenomenon also implicates the higher education milieu. An illustration given by Lee (2007) portrays that a number of lecturers, regardless their seniority in teaching in higher learning institutions, are often quite challenged to encourage interaction, questions and critical discourse among the students.

Undeniably mastering scholarship in certain fields of knowledge, educators' content expertise may not necessarily construe effective teaching. Some educate the students believing that the emphasis of the teaching and learning is on the end product rather than the process. Grades are paid greater attention of which learners are expected to score well in tests and examinations. The process of gaining knowledge is inevitably taken for granted by some learners as knowledge is mostly 'fed' by the educators. This is undesirable, because mistakenly conseptualising learning as the outcome of instruction often impedes rather than facilitates meaningful learning (Wells, 2010).

Hence, dialogue is believed to be brought to the forefront as it may allow learners to undergo learning as a significant process (Anis Shaari, Aswati Hamzah, \& Teo, 2016; Rosnani Hashim, 2017). Why dialogue? Having features that apply the concept of constructivism, dialogues engage learners more actively and deeply in the teaching and learning process. It provides educators and learners equal opportunity to query or to utter any idea about the agreed line of inquiry. In line with Vella's (2002) discrete way of defining dialogue, 'Dia' means 'between', 'logos' means 'word' and dia + logue $=$ 'the word between us' (p. 3), it is explainable how an idea is expanded through a shared understanding and collaborative contribution that occur between every single participating learner and educator.

Albeit its effectiveness, the term dialogue itself still seems unfamiliar to some of those who are involved with the teaching and learning endeavour when asked randomly by the researcher. Although most research on constructivism, which encourage thought articulation among the learners, show positive effects in facilitating learning, teachers frequently feel difficult to employ constructivism in their teaching and learning process (Muijs \& Reynolds, 2005). Having said that, Wells (2010) indicates that there have been several studies that note the dearth of dialogic practice across courses offered at educational institutions. This suggests a remarkable need to ponder upon the meaning of a dialogic orientation to teaching and learning as how Kim (2004), who has transformed her perspective 
from curriculum as knowledge dissemination to dialogic learning, has suggested. With regard to the matter of understanding dialogue, cultivating a better discussion remains an enduring problem in education (Abdul Shakour Preece \& Adila Juperi, 2014; Feito, 2007) and to identify ways in which it could be achieved, the understanding of what really happens within the dialogic process should be first deepened.

Of such encouragement, the researcher made an attempt to observe and describe the practice of dialogue as a form of teaching and learning in a Malaysian higher learning institution milieu. The understanding of such practice is warranted as related studies conducted in Malaysia are mostly researched within the settings of elementary and secondary schools (Adila Juperi, 2010; Moomala Othman, 2005; Rosnani Hashim, 2003). Despite the rare practice among today's teaching practitioners (Rosnani Hashim, 2017), the education of higher learning institutions is enlightened, for there are a number of educators who advocate dialogue as a form of teaching and learning. It is a unique case that they choose to dialogically conduct their lessons despite the difficulties they face in employing it.

\section{LITERATURE REVIEW}

\section{Freire's Theory of Dialogue}

The emergence of Freirean Dialogic concept began when Paulo Freire strongly opposed the "banking" concept of education, in which education is deemed as "an act of depositing" (Freire, 1970, p. 58) - educators are the depositors and learners are the depositories. Knowledge is merely disseminated or deposited by the educator to the learners. In this concept of banking education, learners become ignorant while the educator acts as an expert. The prior question here is whether the learners would ever become experts if they keep on receiving knowledge without being given opportunities to explore and construct knowledge. In lieu of this, Vygotsky has been firm in highlighting the importance of students' knowledge construction which is best accomplished through social interactions (Santrock, 2006).

Freire subsequently established a new concept and practice that is paradoxical to the banking concept of education. It was termed as problem-posing education (See Figure 1). It is with this problem-posing education that the concept of dialogue emerged. According to Freire, "the teacher is no longer merely the-one-whoteaches, but one who is himself taught in dialogue with students, who in turn while being taught also teach" (Freire, 1970, p. 67). Providing opportunities for learners 
to express themselves is of fundamental importance (Freire, 1993). Freire (1997) also writes that the role of the educator is to share with the learners the criticalness in constructing knowledge. The idea of giving space to learners remains the same despite the vast distance of Freire's thinking years (from 1970 to 1997).
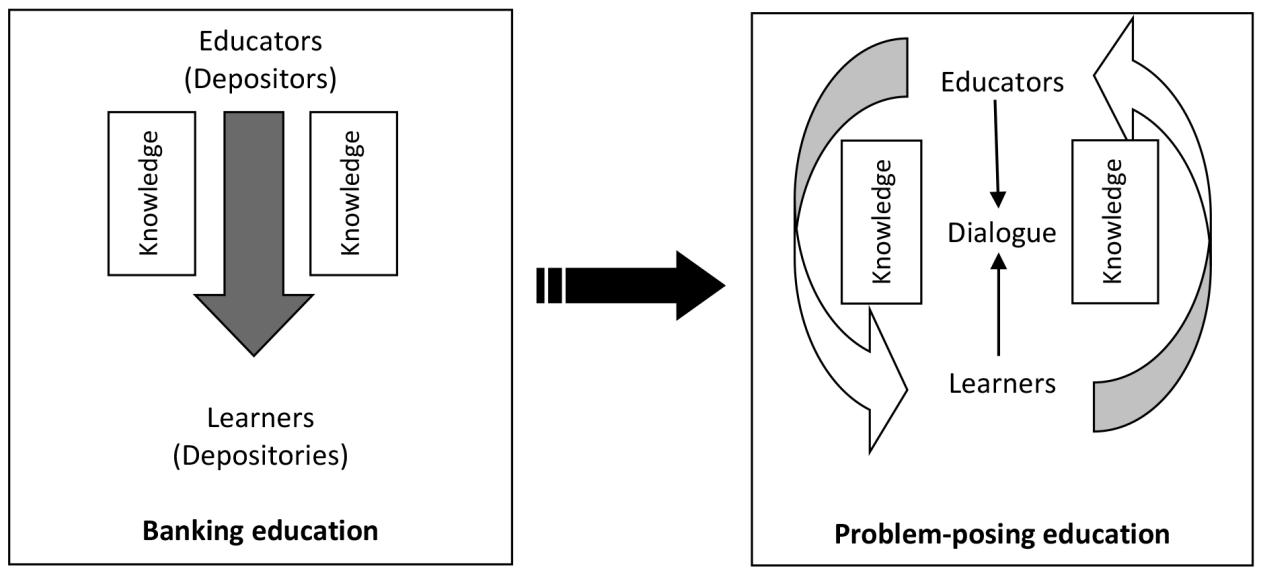

Figure 1. Contradictory educator-learner relationships between the banking education and the problem-posing education (Anis Shaari \& Hairul Nizam Ismail, 2010)

\section{Previous Related Studies on Dialogue}

Other than the mentioned studies conducted in Malaysia (Adila Juperi, 2010; Moomala Othman, 2005; Rosnani Hashim, 2003), in a classroom in Florida, Hadjioannou (2007) examined the features of the dialogic environment. Seven aspects of the classroom environment were discussed: physical environment, curricular demands and enacted curriculum, teacher beliefs, student beliefs about discussions, relationships among members, classroom procedures, and norms of classroom participation. In this study, the educator believes that openness is important, thus shapes her to invite such students' contributions and construction of understanding. Besides, it was also discovered that cultivating amiable relations between the teacher and the students, which involves trust, respect and positivity, is a powerful factor in sparking an authentic discussion.

A quite similar research was conducted in Southern California by Webb, Franke, De, Chan, Freund, Shein and Melkonian (2009). This study, similar to the study of Hadjioannou (2007), partly investigated educators' instructional practices in a dialogic context. Results demonstrated that probing students' explanations to uncover details of their thinking and problem solving strategies portrayed a strong relationship with students explaining, in spite of various instructional practices 
educators used to orchestrate the dialogue. The findings of Webb et al.'s (2009) study differ from the one conducted by Hadjioannou (2007) that Webb et al. (2009) discussed the techniques of getting the students explain well while Hadjioannou (2007) focused more on the psychological aspects of teachers' role in ensuring a successful dialogue.

In her other work, Webb (2009) reviewed numerous studies which had explored the roles of teachers in promoting collaborative dialogue in small groups. This review revealed various dimensions of the teachers' role in facilitating dialogue. The dimensions include the preparation of students for dialogue, group formation, the structuring of group task, and the influence of teachers' discourse in students' interaction. This review compiled the practices and strategies as well as socioemotional processes which teachers may apply in promoting students to have the ideas heard and to be able to elaborate the idea well.

Rule (2004) carried out a historical case study of a South African adult education project, particularly in Johannesburg, in such a place where possibilities of dialogue between black and white, between rich and poor, between employer and employee were suppressed by the Apartheid policy. The study found that the suppression turned into emancipation when dialogue was implemented. Results found several conditions for dialogue which include trust, attitude of openness, safety physical place, a project ethos which encourage learners to express themselves, and commitment. It is crucial to note here that these conditions do not always ensure smooth dialogue, for the possibilities for conflict, struggle and pain are always there to interfere. Results also characterised dialogue as a responsibility in the context the participants lived in.

Also studying dialogue, Bartlett (2005) conducted an ethnography research in Joao Pessoa, Brazil, among three nongovernmental literacy programmes inspired by Freire's philosophy. Interestingly, Bartlett (2005) described the setting of the research as "the cradle of Freire's radical pedagogy" (p. 349). This research discovered that the three programmes were all of Freire's advocates, in which the teachers and learners there were really applying the dialogic education the way Freire propagated. One of the focuses of the study was the teacher-student relationship. It was uncovered that everybody worked hand in hand to establish a climate of friendship, trust and equality inside the classroom. The centrality of emotion was evident throughout the study. Besides, the element of knowledge was also studied and results showed that 'popular' knowledge or working-class knowledge was brought into the classroom. In other words, prior knowledge was elicited from the students to help them discover new knowledge. This idea is very much similar to the aspect of constructivism in knowledge building. 
Innes (2007), on the other hand, performed a study examining the quality of discourse in self-managed, problem-based learning groups in Science subject in a formal higher learning setting. Learners were assigned tasks to discuss in their group and to later present the discussion. The study discovered a low incidence of high quality dialogue, in which the dialogues were lacking in high-level analysis of the problem and the greater part of the time was spent for presentation preparation.

Different views were uncovered through the experience of two educators, Gunnlaugson and Moore (2009), in developing and facilitating two dialoguebased courses in two different universities in North America. Moore reflected that the dialogue she was conducting was aligned with the aim to convert students from passive to active, and from dependent to independent and interdependent, besides to develop higher order thinking and communicative skills. Similar to the research carried out by Bartlett (2005), Hadjioannou (2007) and Rule (2004), Moore also emphasised on the importance of openness and positivity. On the other hand, Gunnlaugson has made use of the technology advancement by conducting a virtual or an online dialogue. Gunnlaugson found that students are encouraged to improve intrapersonally and interpersonally through dialogue. He, too, discovered that openness is the key factor to help increase students' performance.

\section{METHODOLOGY}

Attempting to describe the practice of dialogic teaching and learning, specific classes that practiced dialogue were observed. Two groups of different courses Profesional Development (PD) and Current Issues in Education (CIE) - which were facilitated by the same lecturer - Madam Ruqayyah (pseudonym) were implicated. The two groups were chosen in accordance with the lecturer's recommendation as the dialogic method has been employed in the teaching and learning of both courses for at least 7 times per semester. The courses are offered in the final semester to students enrolling in the Bachelor of Education Programme at a higher learning institution in Malaysia.

An observation guide was prepared to aid the researcher in taking field notes, besides providing a focused framework to be followed. The guide was prepared based on the 'checklist of elements to be observed' by Merriam (2009, pp. 120121). It included such elements to be observed:

1. The physical setting

2. The participants 
3. Activities and interactions

4. Conversation

5. Subtle factors

6. Observer's own behaviour

Throughout the lesson observations, the researcher played the role of nonparticipant observer (Merriam, 2009), who was less intrusive and less likely to get emotionally involved (Gay, Mills \& Airasian, 2009). The observed teaching and learning processes were recorded audiovisually. Descriptive and reflective field notes, too, were written throughout the observation. The researcher analysed the data by reviewing the video and the field notes several times until significant chronological episodes of a dialogic process is achieved. Certain insignificant observations were reduced and omitted. The data were then described and discussed in a qualitative narrative. Besides being used to analyse the observation, it is to note that the video was later shown to the experts in order to verify the reported findings as to ensure the research authenticity and trustworthiness. Of the length and the number of observation conducted, the researcher stopped after the fifth observation as it was believed to provide enough data for the study when the phenomenon pattern could be observed and predicted.

Due to the nature of qualitative studies which are adaptive to the phenomenon, this research paid attention to several ethical issues. The research process began by obtaining an informed consent from the gatekeeper, i.e. the Dean of the respective faculty under study. Besides, the issue of confidentiality was also given a great emphasis. To uphold the confidentiality, real names of the participants were not used. Instead, pseudonyms were utilised as to avoid violating the privacy and harming the reputations of every single participant. Another ethical issue to be addressed is the relationship between the researcher and the participants. As the research activity required the researcher to have a number of visits to the site, the expectation was that she might get personally engaged with the research context, which included the participants of the research. According to Gay, Mills and Airasian (2009), it is good that the closeness between the two parties may bring about deep and rich data, yet it may also result in unintended influences on objectivity and data interpretation. To get this problem avoided, the researcher had to stay focused on the objectives of the research, besides practicing epoche (Merriam, 2009) and reflexivity (Gay, Mills \& Airasian, 2009) 


\section{FINDINGS}

\section{Professional Development (PD) Group}

As for the PD group, the lessons took place in a classroom setting. To physically describe it, the seating arrangement was exactly of a lecture-based style where desks and chairs were arranged facing the white board and the screen. Like any other traditional classroom, there was a teacher's table at the front corner of the class. In terms of the space and proximity, the desks were positioned closed to one another and that portrays side by side seating among the students. The classroom was equipped with a set of computer and an LCD Projector. There were altogether 12 units of lights and the room was accommodated with two large air conditioners. The room was quite cozy as the windows were blinded with brown curtains.

Attending the lesson that day (first observation) were 19 students. It was a full house. All of them dressed very formally and properly. With such corporate looks, the students showed the researcher that they seemed ready to learn. They took their seats and Madam Ruqayyah positioned herself at the back of the class. There were also some students who were late for the lesson. The lecturer, Madam Ruqayyah, however did not seem to scold them or say a word about their late coming. Instead, she just smiled at them.

Few minutes later, the class session began with students' presentation. It could be seen that a system had been established where Madam Ruqayyah did not have to initiate the teaching and learning session. Instead, all the learners seemed to have understood that they were expected to start the session by themselves. As everyone was ready, a group of four students presented the assigned topic.

Discussing the issues related to Leadership, the first presenter took about 21 minutes to introduce the topic as well as to bring out the issue. In doing so, she asked everyone to imagine becoming a school principal. She was able to draw other students' attention. The audience gave feedbacks whenever the presenter enquired them. It was also observed that she managed to grab everyone's mind to focus on her by relating the discussion to real life experiences. However, even though all students looked very attentive at the very initial part of the presentation, a student was seen yawning. Most probably, it was due to too long a presentation, let alone the class session was conducted in the afternoon, when the energy level starts to decrease.

Taking approximately 30 minutes, the second presenter recaptured the students' concentration by posing few questions. However, it is interesting to report such an 
episode when the presenter seemed to experience loss of words. The short pause invited her friends (among the audience) to help her out. They shouted out few words as to assist the presenter to continue her presentation. This episode indicates that the students were listening well to the presentation. Besides, it portrays cooperation among the learners. They were also showing that egocentrism did not exist within the four walls.

Taking his turn, the third presenter made the class livelier when he started his presentation by wrongly pronounced a word. It was a great moment to see helps offered by friends in correcting the pronunciation. The presenter also asked his friends few questions and they answered him happily. He even cracked several jokes. It made the presentation less formal and it somehow invited every class member to join in the discussion. The students were freely interrupting the discussion and making attempts to share their thoughts and experiences. Besides allowing the audience to voluntarily take part in the discussion, the presenter did not forget to call upon some names of those who did not seem to participate.

When it comes to the last presenter, she surprisingly highlighted some negative things that she had encountered throughout the teaching practicum (particularly regarding the matter of leadership). It could be identified that she looked at things from only one side and acknowledged only those who had similar sorts of experience to the ones of hers. Ignoring those who did not see eye to eye with her, it could be inferred that she was not that open-minded at times. Nevertheless, it is undeniable that she was brave and confident enough to bring out the negativities related to the issue discussed.

In short, it could be said that the whole group presentation was pretty long. Nonetheless, none of the student was caught sleeping throughout the whole session. Interestingly, the students were allowed to eat and drink in the classroom while listening and responding to the presentation. This portrays the culture of openness within the classroom setting.

Continuing the presentation, began was the session of questions and answers (Q\&A). The dialogue was clearly seen during this latter part of the lesson procedure. To begin the session, a female student gave her opinion related to the matter discussed in the presentation. She was actually counter-arguing one of the thoughts posed earlier. Another student, of a male audience, enquired something as to respond to the opinion. This invited the third student to take part in the dialogue by responding to the inquiry. Adding to the answer given by the third participant, one of the presenters expressed her opinion by asking everyone to see the matter from a different perspective. The dialogue was continued with more ideas coming 
out. More students got involved - expressing their agreements and disagreements over statements pertaining to the issue presented. Different voices made the session a dialogic one. This is not to mention some of the non-verbal behaviours, such as nodding, showing thumbs-up, smiling, clapping, raising hands, and establishing eye-contact, observed throughout the session.

However, it is undeniable that there were, still, some students who preferred to stay quiet and became the dialogue observers. As for the lecturer, she, too, did not seem to interrupt the dialogue occurred among the students, especially at its initial part. It was only towards the real end of the class session that the lecturer came into the picture. She tried to respond to certain segments of ideas that indicated needs to be clarified on. She, too, enquired few questions to the students and some of them made attempts to respond. Finally, after such a long presentation and discussion, the session was wrapped up.

A week after the first observation, the second observation for the PD group took place. It was raining heavily while the lesson was conducted. The flow of the lesson procedure was just about the same as the previous lesson. It started off with the students' presentation and followed by the Question and Answer (Q\&A) session. Everyone seemed to listen to the presentation very attentively despite the heavy rain outside. It made the observer questioned herself few times whether these students were really listening.

Nonetheless, compared to the previous observation, among the differences that could be observed were in terms of the presentation skills. One of the presenters involved the audience in the discussion of the topic by asking a number of them to read certain statements appeared on the slides. Another presenter could be said to have such a good presentation skills, in which he managed to attract others to join in the discussion. The dialogue happened quite naturally when the students participated in the discussion without seeming to realise the intellectual conversation was actually taking place. The presenter, too, was smart as he knew how to play with the tone and intonation while delivering his content, as well as to utilise the pauses effectively as to allow the audience to digest the information. However, similar to the previous lesson, the long presentation finally made the lesson quite a monotonous one before the onset of the Q\&A session. The class turned to be livelier when most students started to think of ideas and express them aloud. 


\section{Current Issues in Education (CIE) Group}

For the CIE group, all the three observations took place at the same venue. The physical description of the classroom setting is quite similar to the one where the lessons for PD group were conducted. The seating arrangement was alike the traditional teaching and learning where all the desks faced the board and the screen.

In terms of the activities and interaction occurred throughout, the lesson procedure was equally the same as in the PD group. Of 22 students in the class, four students played the role as presenters and the remaining number was expected to listen, contribute and respond to the matters discussed. The lesson began with the presentation of the topic. It could be reported here that no interruption or interaction occurred while the first, the second and the fourth presenters were sharing the information. However, it was interesting to see a student raised his hand right away when the third presenter was taking the turn. He invited the audience to join in only by asking, "Any questions?" After the presentation session, followed was the Q\&A session. In this very session, the classroom turned to be louder. Voices started to be heard. From a monotonous lesson, it became quite an enlightening one. The students looked happy and more importantly, they looked very close to one another. This may explain the reasons the students seemed comfortable contributing ideas. In spite of that, still, there were some students who preferred to play with their hand phones.

The second observation discovered a little difference from the first one. Interaction could be obviously seen between all the presenters and the students. Even though the first presenter did not seem to allow interaction at the initial part of the presentation, he gradually changed the classroom condition when he posed a question to one of the active girls in the class. In short, he somehow managed to spark a dialogue throughout the presentation when the question invited more students to respond. When it comes to the Q\&A session, the presenters asked whether the students had any inquiries. The class was very quiet. To break the silence, one of the presenters gave a situation. The situation could be regarded as a good codification as it sparked the dialogue. This was true when the audience started to respond to the given situation. When it reached the solution of the situation, no more questions was asked. The whole class became quiet again. The presenters seemed to crack their heads as to ask more questions. The same person responded. It was only when a more controversial question was asked that the students began to be loud. As what happened in the PD group, the lecturer, Madam Ruqayyah joined the discussion at the end of the lesson. Standing in the middle of the classroom, she responded to several matters and she finally wrapped up the session. 
In the third observation, the flow of the lesson could already be predicted. It was quite identical with the previous observations, where the participation of learners throughout the presentations actually depended on the presenters. In this third lesson, all presenters managed to get the audience involved except for only one presenter. The second presenter allowed no interaction to occur throughout the presentation. The lesson continued as how it was seen in the previous observations.

\section{DISCUSSION}

From the observations conducted in both groups, the lesson procedure could be observed to be similar despite the different courses taught. Perhaps, it is the nature of the courses, which are situational and context-based, that allows the same flow of the lessons. In both courses, the lecturer gave autonomous power to the learners to determine the success of the session. Not only that, the aspect of openness was obviously seen that it provided a comfortable zone for the learners to voluntarily involve in the in-depth discussion. The learners, however, were the ones who were expected to play their responsibility throughout the teaching and learning period. This explains the differences that occurred between every lesson and between each group.

The overall process portrays that the dialogue (the in-depth discussion) did occur within the teaching and learning process. Indeed, the educator did play her role in allowing space for learners to share thoughts and ideas. Learners, too, were actively participating in the dialogue. However, it could still be said that some of the learners were still adjusting themselves towards the practice of dialogue. The dialogues in both courses, nevertheless, became more dialogic towards the end of the class duration. This was especially true when the lecturer started to interrupt and took control over the discussion. Such a phenomenon portrays the dependency of the learners on the educator in the process of slowly reducing the learners' unfamiliarity with the dialogic teaching and learning. Within the expectation of having all learners to be eager to contribute in each dialogic session, the passiveness was still inevitable. Having discussed that, to ponder upon the question of how dialogic it is, it has to depend on few factors such as the role of the educator and the learners, the physical setting of the classroom, the topic discussed, and the ability of the learners.

With regard to the practice of dialogue, part of the study findings is found to coincide with studies by Bartlett (2005), Gunnlaugson and Moore (2009), Hadjioannou (2007) and Rule (2004). This is particularly of the affective or psychological factors which are believed to help spark the dialogue. As uncovered in the current 
research, factors like openness, trust, respect, positivity, safety physical place, a project ethos which encourage learners to express themselves, and commitment are seen as essential, similar to what have been found in the mentioned three previous research. The centrality of positive emotion is given great emphasis in ensuring a success of a dialogue. This, in a way, implies the need for educators to recheck their roles in creating such supportive learning climate.

Rule (2004), however, states that the evidence of such psychological conditions do not always ensure smooth dialogue, as the possibilities for conflict, struggle and pain are always there to interfere. The result of the current research could be said to correspond to Rule's (2004) findings, for there existed several downsides throughout the dialogue where some learners were affected by certain words expressed by other dialogue participants.

In terms of the instructional practices, a research conducted by Webb et. al (2009) demonstrated that probing students' explanations by an educator portrayed a strong relationship with students explaining, in order to orchestrate the dialogue. The idea could be seen practiced by Madam Ruqayyah throughout the dialogic teaching and learning. A difference, however, did exist. In Madam Ruqayyah's class, the process of probing the explanations was not only done by her as an educator. In fact, the responsibility was also shared by the learners, who seemed to have understood their roles in manoeuvring their own learning.

\section{CONCLUSIONS AND IMPLICATIONS}

\section{A Process of Setting the Stage: Catering for Learners' Unfamiliarity of Dialogue}

The findings of the research portray learners' unfamiliarity of the dialogue practice. This may not apply to all learners. However, the passive responses some of them contributed throughout the teaching and learning sessions did illustrate their uneasiness with the dialogic method. This is especially true for the question and answer session in which learners are expected to voice out any questions, ideas or responses. Some of them seemed yet to realise that a successful dialogue involves not only paying attention and listening to other people's thoughts, but to also have the courage to speak up and share their ideas (Petress, 2001).

This problem of unfamiliarity is probably due to the dearth of exposure the learners have towards the idea of contributing thoughts and views, especially throughout the early, primary and secondary education. In fact, even at the university level, 
the claim the research participants made that university learning is much about attending lectures and sitting for examinations, is another crucial aspect that needs to be taken into consideration. Causing learners unfamiliarity with the dialogic method, this so-called conventional method of teaching and learning is in line with Norizan et al. (2010) who believes that teaching is often linked to lectures and notes. The statement supports McCain's (2005) claim that postsecondary educators have the tendency to reinforce school skills than real-world skills, in which they focus more on training the learners to do well in written assessments to score good grades. In this form of teaching, memorisation of content is given central emphasis. The question is 'should the education be treated such a way?'

With such realistic yet ambitious aims, visions and missions the educational institutions have, regardless of the size and the power of each, it could be implied that the strategies of meeting those objectives ought to be reflective of one another. To illustrate, of producing individuals with high cognitive and affective skills, it has been a question whether the teaching methodologies employ activities requiring high order thinking and affective elements. Have educators, all this while, instilled balanced lessons within learners? Have educators in schools prepared the learners for the thinking-based learning in university? And have educators in university prepared learners for the challenging world of career and life survival? Not to put the blame on the educators and learners, of course, there are many other elements that require a closer look such as the curriculum design, the policy of Malaysian education system, and the culture of Malaysian learning.

Of various reasons contributing to unfamiliarity among learners when it comes to dialogic teaching and learning, it would remain a problem if they are not given the chance to experience it themselves. It is true that the awkwardness learners feel throughout the lesson is inevitable, yet, it is highly believed that they will gradually improve as they continually participate in the dialogue. This is as proven in the research findings where the educator observed the positive impacts among the learners despite their feeling of intimidation at the initial stage of the dialogic process. To have the learners speak up even a word after so long of not voicing out anything in the discussion is a great beginning to listen to more of their critical ideas and views.

In brief, it could be concluded that dialogue is a good 'icebreaking' method in catering for learners' unfamiliarity with the idea of being an active learner. As for this research subjects, it is novel for many of the learners at the beginning of their very last semester. Therefore, it could be implied that the dialogue employed by the educator is a form of setting up the stage for the learners to dialogue more engagingly and critically, besides to experience the various benefits a dialogue brings about. 


\section{Practicality of dialogue employment for young adult learners}

One basic assumption Vella (2002) makes is that "adult learning is best achieved in dialogue" (p. 3). Even though this very research did not serve to prove or reject any hypothesis, the findings in some way suggest that Vella's (2002) assumption ought to be accepted. As learners in higher learning institutions are basically those who are stepping into adulthood and are therefore termed as young adult learners, the employment of dialogue is seen as complimentary to what they need.

Of the practice of dialogue within the two groups under study, the findings portray a good match between its elements and Vella's (2002) twelve principles for effective adult learning:

1. Needs assessment (participation of the learners in naming what is to be learnt)

2. Safety (in the environment and the process, context for learning is created and it ought to be made safe)

3. Sound relationship (between teacher and learner, learner and learner)

4. Sequence of context and reinforcement

5. Praxis (action with reflection or learning by doing)

6. Respect for learners as decision makers

7. Ideas, feelings and actions (cognitive, affective and psychomotor aspects of learning)

8. Immediacy of learning

9. Clear roles and clear development

10. Teamwork and use of small groups

11. Engagement of learners in what they are learning

12. Accountability (how do they know they know?) (p. 4)

The dialogue practiced by Madam Ruqayyah and her students illustrate clear division of roles in which learners were empowered by having the autonomy to decide upon the topic of the presentation as well as to discuss freely. No one in the classroom was subjected to stay quiet and passive. Yet, equal chances were given to each and every learner to be heard. This suggests good relationships among the learners themselves and sound space, too, was formed between the learners and the educator. This, in a way, created such a safe learning ambience for the learners. In brief, all Vella's (2002) twelve principle were seen in the practice of dialogic teaching and learning studied. 
Not only that, the findings also show that the educator exercised McCain's (2005) six ways to teach for higher learning, in which the learners are of adult counterparts:

1. Educators must resist the temptation to tell (stand and deliver approach)

2. Educators must stop teaching decontextualised content

3. Educators must stop giving students the final product of teacher's thinking

4. Educators must make a fundamental shift from 'teaching' to 'problem solving'

5. Educators must progressively withdraw from helping students

6. Educators must reevaluate evaluation

Not allowing the learners to only sit and absorb, the educator is believed to employ what it needs to help these young adult learners in becoming quality and holistic individuals. Nonetheless, it is important to note here that an irony does exist. From the findings, despite the expectation of such university students being adults when it comes to learning, yet in reality, there are still learners who are not that ready to be given more responsibility of learning. This is probably due to the previous learning experiences that they were not exposed to such dialogic ambience.

Hence, for learners who are exceptionally active, dialogue is simply a practical method. As for those who seemed a little unprepared for such learning, dialogue is still seen a practical way for them, yet patience is highly needed and more space is extremely required to train these learners to gradually become 'adults'. Indeed, more dialogues are needed for them!

\section{A Shared Responsibility}

The observation undertaken reveals that much space was given to learners in voicing out their thoughts. This occurrence suggests that the educator did not hold the responsibility alone, yet the role in the teaching and learning was delegated to the learners as well. As there were learners seen to participate without being prompted or requested, a conclusion could be drawn that learners, too, together with the educator shouldered certain portion of responsibility throughout the process.

Sharing the responsibility, the practice conforms Freire's (1970) belief that "the teacher is no longer merely the-one-who-teaches, but one who is himself taught in dialogue with students, who in turn while being taught also teach" (p. 67). It also agrees to Freire's another claim in his book Pedagogy of the Heart (1997), that the role of the educator is to let both him or her and the learners share the criticalness in constructing knowledge. 
In lieu of Freire's (1997) claim above, the togetherness discovered throughout the teaching and learning process does indicate the encouragement of higher order thinking among the learners. Besides being shaped to be critical thinkers, learners, too, were indirectly trained to build up the courage to speak up. The provision of space to the learners allows them to experience the comfort in learning despite the little force they need to have within them in order to get them verbalise their thought. When the power being delegated equally, learners were seen to have the chance to grow both cognitively and affectively, thus enhance their behaviour in the learning process.

Opening channels for learners to express themselves (Freire, 1993) also allows them to be more aware of their own learning. The term 'responsibility' is indeed important in the process of constructing knowledge as it is well understood that learning requires endless effort of a person called 'learner' or 'knowledge seekers'. This is more relevant when it comes to university learning. Learners ought to be aware that they need to pull their own weight. In a nutshell, the dialogue under study is found to practice a shared responsibility among its participants regardless of the level of authority within the classroom setting.

\section{Embracing the 21st Century Skills: Dialogue as a Bridge to a Real World}

Of the findings uncovered in this very research, it is agreed that dialogue is not solely a method of teaching and learning in the classroom, yet, "it is part of a wider social fabric of values, employment and civic life" (Harkin, Turner \& Dawn, 2001, p. 5). The dialogue was found to discuss real-world issues, particularly pertaining to the education field. It, too, offers various benefits to learners, especially in training them to be critical and courageous at the same time. Not only that, learners are given a chance to develop their self-potential in whatever things they undertake. This is viewed as such a big assistance in aiding the learners to prepare themselves to fulfil the employment market.

In a way, this addresses Walker (2006) who expresses her anxiety when the issue of higher education is discussed, as the perspective on higher learning as fostering economic development and economic life, as well as nurturing 'educated hope' and ethical and critical citizens seem increasingly at risk. Besides, according to Harkin et al. (2001), learners, largely, fail to meet their potential because they are mostly found unengaged with the real-world learning. They further claim that "much education is an agony of irrelevance and boredom" (p. 4). It is the time to ponder and act upon ways to take our education and practice forward in a progressive direction (Walker, 2006). 
Interactively engaging learners with issues matter to them, as what happened in the teaching and learning observed, it is believed that the method may ensure useful knowledge to be applied in their lives. As Mason (2008) and Rosnani Hashim (2017) believe, teaching should be made a platform to produce active rather than passive learners, given the demands of the challenging 21 st century, which apparently needs communicative, collaborative, creative and critical learners. Hence, it could be implied that dialogue is one of the ways out!

\section{REFERENCES}

Abdul Shakour Preece \& Adila Juperi. (2014). Philosophical inquiry in the Malaysian educational system - reality or fantasy? Analytic Teaching and Philosophical Praxis, 35(1), 26-38.

Adila Juperi. (2010). Philosophical inquiry in Islamic education and its effect in the development of questioning skills among secondary school students. Unpublished Master's Dissertation, International Islamic University Malaysia, Gombak.

Anis Shaari \& Hairul Nizam Ismail. (2010). It is time to dialogue. Diges Pendidik, 10(2), 89-96.

Anis Shaari, Aswati Hamzah \& Teo, L. Y. (2016). Promoting humanistic education: A look into Freirean dialogic teaching and learning. Bulletin of Educational Research, Innovation and Thought, 16, 26-33.

Bartlett, L. (2005). Dialogue, knowledge, and teacher-student relations: Freirean pedagogy in theory and practice. Comparative Education Review, 49(3), 344.

Feito, J. A. (2007). Allowing not-knowing in a dialogic discussion. Retrieved 1 November 2009 from http://academics.georgiasouthern.edu/ijsotl/v1n1/feito/ij_feito.htm https://doi.org/10.20429/ijsotl.2007.010105

Freire, P. (1970). Pedagogy of the oppressed. New York: The Continuum Publishing Company.

Freire, P. (1993). Pedagogy of the city. New York: The Continuum Publishing Company.

Freire, P. (1997). Pedagogy of the heart. New York: The Continuum Publishing Company.

Gay, L. R., Mills, G. E. \& Airasian, P. (2009). Educational research: Competencies for analysis and applications. New Jersey: Pearson.

Gunnlaugson, O. \& Moore, J. (2009). Dialogue education in the post-secondary classroom: Reflecting on dialogue processes from two higher education settings in North America. Journal of Further and Higher Education, 33(2),171-181. https://doi. org/10.1080/03098770902857395

Hadjioannou, X. (2007). Bringing the background to the foreground: What do classroom environments that support authentic discussions look like? American Educational Research Journal, 44(2), 370-399. https://doi.org/10.3102/0002831207302173

Harkin, J., Turner, G. \& Dawn, T. (2001). Teaching young adults: A Handbook for teachers in post-compulsory education. London: Routledge Falmer.

Innes, R. (2007). Dialogic communication in collaborative problem solving groups. International Journal for the Scholarship of Teaching and Learning, 1(1),1-19. https://doi.org/10.20429/ijsotl.2007.010104 
Kim, Y. J. (2004). Finding dialogic curricula: A transformative journey through doctoral studies. Curriculum and Teaching Dialogue, 6(2), 81-88.

Lee, L. M. (2007). The construction of a constructivist: Learning how to teach without teaching. Pulau Pinang: Penerbit Universiti Sains Malaysia.

Mason, M. (Ed.). (2008). Critical thinking and learning, in critical thinking and learning. Oxford: Blackwell Publishing Ltd. https://doi.org/10.1002/9781444306774

McCain, T. (2005). Teaching for tomorrow: Teaching content and problem-solving skills. Thousand Oaks, CA: Corwin Press.

Merriam, S. B. (2009). Qualitative research: A guide to design and implementation. San Francisco: Jossey-Bass Publishers.

Moomala Othman. (2005). Critical thinking and reading skills: A comparative study of the Reader response and Philosophy for Children program approaches. Unpublished $\mathrm{PhD}$ dissertation, International Islamic University Malaysia, Gombak.

Muijs, D. \& Reynolds, D. (2005). Effective teaching: Evidence and practice. London: SAGE Publications.

Norizan Md. Nor, Noriah Mohamad, Hasuria Che Omar \& Ruslan Rainis (2010). The direction and future of higher education in Malaysia. In Zailan Moris (Ed.). 50 Years of Higher Education Development in Malaysia (1957-2007) (pp. 148-176). Pulau Pinang: Penerbit Universiti Sains Malaysia.

Petress, K. (2001). The ethics of student classroom silence. Retrieved 1 November 2009 from http://www.umpi.maine.edu/ petress/essay28.pdf

Rosnani Hashim. (2003). The teaching of thinking through the philosophy for children approach in Malaysia. (Unpublished research report). Gombak: International Islamic University Malaysia.

Rosnani Hashim. (2017). Pedagogi hikmah: Kaedah pengajaran kemahiran berfikir kritis, kreatif, kolaboratif dan komunikasi. Selangor: Pusat Pengajaran Kemahiran Berfikir, Universiti Islam Antarabangsa.

Rule, P. (2004). Dialogic spaces: Adult education projects and social engagement. International Journal of Lifelong Education, 28(4), 319-334. https://doi.org/ $10.1080 / 026037042000233476$

Santrock, J. W. (2006). Educational psychology: Classroom update: Preparing for praxis and practice. Boston: McGraw Hill.

Vella, J. (2002). Learning to listen, learning to teach: The power of dialogue in educating adults. San Francisco: Jossey-Bass.

Walker, M. (2006). Higher education pedagogies. England: Open University Press.

Webb, N. (2009). The teacher's role in promoting collaborative dialogue in the classroom. British Journal of Educational Psychology, 79(1), 1-28. https://doi. org/10.1348/000709908X380772

Webb, N., Franke, M., De, T., Chan, A., Freund, D., Shein, P. \& Melkonian, D. K. (2009). 'Explain to your partner': Teachers' instructional practices and students' dialogue in small groups. Cambridge Journal of Education, 39(1), 49-70. https://doi. org/10.1080/03057640802701986

Wells, G. (2010). Dialogic inquiry in education: Building on the legacy of Vygotsky. Retrieved 10 February 2010 from http://people.ucsc.edu/ gwells/Files/Papers Folder/Building\%20on\%20Vygotsky.pdf 